\title{
İmparatorluk ve Ulus Devlet
}

\section{Mihriban Şenses*}

\section{Öz}

Elinizdeki metinde tanımlarından, işleyiş mantığından, başarı ve başarısızlıklarından hareketle imparatorluk ile ulus devlet arasında kısa bir karşılaştırma yapılmış ve imparatorlukların ulus devletlere göre büyük ölçüde daha heterojen ve uzun süren siyasi birimler olduğu savunulmuştur. Ulus devlet ise milliyetçilik, ırkçıllık, emperyalizm, Avrupa-merkezcilik, jakobenizm realitelerinden hareketle eleştiriye tabi tutulmuştur. Bilindiği üzere imparatorluklar büyük ölçüde etnik farklılıklar üzerine kurulu iken, ulus devletler diğer ideolojiler gibi Fransız Devrimi sonrasında ortaya çıkan milliyetçilik ideolojisi nedeniyle çoğu zaman etnik farklılıkları göz ardı etmiştir. Bu çalışmada imparatorluk ile ulus devlet arasındaki yapılacak kısa karşılaştırmadan sonra ulus devletlerin istisna, çok-uluslu devletlerin kural olarak görülebileceği ve Türkiye'nin de günümüzde halen "de facto imparatorluk" olması hasebiyle politik vizyonunu buna göre belirlemesi gerektiği ileri sürülmüştür.

Anahtar Kelimeler: İmparatorluk, Ulus devlet, Millet, Milliyetçilik, Avrupa-merkezcilik.

\section{Empire and Nation State}

\section{Abstract}

This text makes a short comparison between the empire and the nation-state based on their definitions, logic of operation, successes, and failures and argues that empires were largely more "heterogeneous", long-standing political units than nation-states. The nation-state, on the other hand, has been subjected to criticism with reference to the realities of nationalism, racism, imperialism, Eurocentrism, and Jacobinism. As it is known, while empires are mostly based on ethnic differences, nation states often ignored ethnic differences due to the ideology of nationalism that emerged after French Revolution like other ideologies. After a short comparison between the empire and the nation state, this article suggests that nation-states can be seen as exceptions while multinational-states can be seen as a rule, and because Turkey still today is a "de facto empire", Turkey's political vision is required to be designated accordingly.

Keywords: Empire, Nation-state, Nation, Nationalism, Euro-centrism.

*Dr. Araştırma Görevlisi | Bursa Uludağ Üniversitesi | mihrisenses@gmail.com ORCID: 0000-0001-8021-9835 | DOI: 10.36484/liberal.599153 Liberal Düşünce Dergisi, Yıl: 24, Sayı: 95, Yaz 2019, ss. 87 - 98. Gönderim Tarihi: 31 Temmuz 2019 | Kabul Tarihi: 11 Eylül 2019 


\section{Giriş}

Özellikle 1970'li yıllardan itibaren politik hayatı ve politika teorisini meşgul eden en önemli konu "ulus-devlet krizi"dir. Bilindiği üzere bu kriz aynı zamanda küreselleşme ile ilişkilidir. Küresel ekonomik piyasanın, ulus üstü ve yerel siyasi yapılanmaların ortaya çıkışı, coğrafi sınırların ve uzaklıkların önemini yitirmeye başlaması ulus devleti aşındıran gelişmeler olarak değerlendirilmiştir. Bütün bu gelişmelerle birlikte ulus devletin merkezi gücü azalmıştır. 1970'lerde başlayan ekonomik bunalım, sanayi toplumundan bilgi toplumuna geçilmesi, SSCB'nin dağılması sonucunda “tek-kutuplu dünya”nın ortaya çıkması ile birlikte ulus devlet artık büyük ölçüde kontrol gücünü yitirmeye başlamıştır. Bu minvalde hiper küreselleşmeciler sınırların ortadan kalktığını ve ulus devletin yok olmaya başladığını ileri sürmüşlerdir. ${ }^{1}$

Michael Hardt ve Antonio Negri ünlü eserleri İmparatorluk'ta benzer bir tezi farklı boyuta taşımıştır. Onlara göre ulus devlet, emperyalizm ve kolonyal imparatorluklar aşılmış, onların İmparatorluk olarak nitelendirdikleri yeni küresel bir egemenlik sistemi ortaya çıkmıştır. Soyut emeğin (maddi olmayan emeğin) yükselişi, sömürünün belirli bir yerinin olmaması, disiplin toplumundan kontrol toplumuna geçiş, geçmiş imparatorluklardaki gibi bir merkezin bulunmayışı (İmparatorluğun Roma'sı yoktur) Negri ve Hardt'ın sözünü ettiği yeni İmparatorluğun özellikleridir. Onlar için nasıl kapitalizm, feodalite sonrası ileri/ci aşamayı temsil ediyorsa, aynı şekilde İmparatorluk da emperyalizm sonrası ileri/ci aşamayı temsil eder. Çünkü bu İmparatorluk'ta aynı zamanda çoğul, heterojen, etkin, özgürlük arzusu taşıyan, İmparatorluğa (ortak düşman) karşı mücadele etme, otonomi ve demokrasiyi gerçekleştirme potansiyeline sahip "çokluk" unsuru bulunur. Bu nedenle Hardt ve Negri İmparatorluğu aynı zamanda bir firsat olarak görür. ${ }^{2}$

Ancak onlar, ortaya koydukları teorinin Marksizm eleştirisi içermesi ve "naif optimizmi" hasebiyle Marksistlerin ve küreselleşme karşıtlarının eleştiri oklarının hedefi haline gelmiştir. Bu eleştirilere göre aslında emperyalizm ve ulus devlet ortadan kalkmamıştır; Amerika’nın mümkün hale getirdiği İmparatorluk, basitçe devrimi hazırlayabilecek bir firsat olarak değerlendirilemez; ayrıca bahsi geçen teori aslında bir nevi Amerikan düzeninin övgüsü olarak da okunabilir.

Bugün ulus devletin miadının dolduğu veya güç kaybettiği eleştirileri aynı zamanda başka eleştirilerle de karşı karşıyadır. Örneğin karşıt görüş,

1 Muzaffer Çağlar Kurtdaş, “Küresel Terör Çağında Ulus Devletin Artan Önemi,” TESAM Akademi Dergisi, Temmuz 2018, Sayı: 5(2), ss. 153-158.

2 M. Hardt ve A. Negri, İmparatorluk, çev.Abdullah Yılmaz, İstanbul, Ayrıntı Yayınları, 2018. 
küresel terörün artmasıyla birlikte ulus devletlerin gücünün azalmadığını, aksine arttığını savunur. ${ }^{3}$ Bugün ulus devlet krizi konusunda tercih edilecek iki yoldan söz edilmektedir: Ya yeni ulusal ideolojiler ve milliyetçilikle küreselleşmeye karşı mücadele edilecek ya da ulus devlet küreselleşmeye ayak uydurarak, çok kültürlülüğü tercih ederek kendisini revize edecektir. ${ }^{4}$

$\mathrm{Bu}$ metinde küreselleşme tartışmasına girmeksizin genel hatlarıyla bir imparatorluk ${ }^{5}$-ulus devlet karşılaştırması yapılmaktadır. Ancak yukarıda yer verilen tartışma da göz önünde bulundurarak ulus devletlerin istisna çok uluslu devletlerin ise kural olduğu söylenebilir. Elinizdeki çalışmada bu fikirden de hareketle bir ulus devlet eleştirisi ortaya konulmaya çalışılacaktır.

Bunun için öncelikle imparatorluk ve ulus devletin nasıl tanımlanabileceği konusunda kısa bir tartışma yürütülecektir. Daha sonrasında imparatorluğun işleyiş mantığı ve uzun soluklu oluşunun temelinde yatan saikler ortaya konulmaya çalışılacaktır. Ardından ulus devletin ortaya çıkışı, milliyetçilik, kolonyalizm, ırkçılık, Avrupa-merkezcilik ve emperyalizm ile bağlantılı olarak ele alınacaktır. Son olarak imparatorluk ile ulus devlet arasındaki farklılıklara değinilecektir. Sonuç bölümünde modern ulus devlet ve cumhuriyet paradigmasından, "ilerleme miti”nden hareketle geçmiş imparatorlukları (özelde Osmanlı’yı) acımasızca eleştirme alışkanlığının gayri adil olduğu, Türkiye Cumhuriyeti'nin Osmanlı'dan mutlak bir kopuş olarak görülemeyeceği ve günümüz Türkiye’sinin halen “de facto imparatorluk” olduğu öne sürülecektir.

\section{İmparatorluk ve Ulus Devlet}

“Gerçi biz evvelce de Türk’tük. Fakat kendimize Türk diyemezdik. Türk sözü, birçok ırkları, kavimleri birleştiren bir imparatorlukta, bir kavmin diğerleri üstünde tahakkümünü hatırlatır ve onları gücendirir diye düşünülüyordu. Halbuki bu imparatorlukta yaşayan diğer ırkların, diğer milletlerin hepsi kendilerini, kendi milletlerinin adıyle tanır ve öyle anarlardı. Benim okuduğum asker mektebine Yemen'den, Kürdistan'dan veya sarayla hısım akraba olan Çerkes köylerinden getirilen imtiyazlı çocuklar, hep milliyetleriyle öğünürlerdi. Bize yukardan bakarlardı. Fakat biz Türkler, kendimizi anlatmak için ırk hüviyetimizi hiçbir zaman dile getirmezdik. Irkımızı da bilmez, ya inkar ederdik. Milletimizin adı geçmek lazım geldiği zaman kendimize sadece:

Osmanlı! der, geçerdik. Hatta dilimizin adı bile Türkçe değil, Osmanlıca'ydı. Tarihimizin de Osmanlı tarihi olduğu gibi. Reddedilen, inkar edilen Türk adına kimsenin sahip çıkmaması için her tedbir alınmıştı. Umumi kanaate göre Türk, kaba, görgüsüz ve kabiliyetsiz varlıktı....Bu milletin tarihi, Osman Gazi'nin çadır kurduğu Söğüt, yahut Domaniç yaylasından başlamıyordu. Milletin ilk varlığı da üç yüz çadır halkından ibaret

3 Kurtdaş, a.g.m., ss. 158, 164.

4 Ergün Yıldırım, “Küreselleşen Dünyada Milliyetçilik,” Doğu Batı, Ankara 2006, Sayı:38, s. 190.

5 Buradaki imparatorluk hiç kuşkusuz Negri ve Hardt'ın sözünü ettiği İmparatorluk değildir. 
değildi. Bu milletin vatanı, Osmanlı devletinin sınırladığı yerlerden bile büyüktü. Onun vatanı Türk milletinin yaşadığı her yerdi. Gerçi bu vatan bölünmüştü. Parçalanmıştı. Millet yer yer esirdi. Fakat:

- Tarih birliği,

- Irk birliği,

- Dil birliği,

- Dilek birliği,

olunca, onun bir gün kurtulması, kalkınması ve kendi toprakları üstünde saltanatını kurması mukadderdir deniliyordu. Çünkü yeni görüşe göre, asolan milletti. Vatan, bu milletin yaşadığı her yerdi."

Şevket Süreyya Aydemir'den yaptığımız bu iktibas bile bize hiç kuşkusuz imparatorluk ile ulus devlet arasındaki farklılığa dair önemli ipuçları veriyor. Ancak bu farklılıkları tartışmaya açmadan önce belki de imparatorluğu ve ulus devleti tanımlamak gerekir. Aslında bu tanımların kendileri de ikisi arasindaki farklılıkları anlamamıza yardımcı olacaktır. Fakat buradaki amacımızın imparatorlukların ve ulus devletlerin tarihçesini veya farklılıklarını uzun uzadıya tartışmak olmadığını belirtmeliyiz. Bunlar, elinizdeki metinde sınırlı şekilde ve genel hatlarıyla ele alınacaktır.

İmparatorluğu büyük, çok farklı etnik toplulukları içeren, fetih yoluyla yaratılan, merkezi bir yönetim yapısına sahip siyasi bir birim olarak tanımlayabiliriz. ${ }^{7}$ Bir başka imparatorluk tanımı şu şekildedir: "Bir imparatorluk diktatöryal çok uluslu bir devlet olmanın ötesinde, son derece merkezileşmiş, toprakları bölgelere ayrılmış, kültürel olarak farklılıkların görüldüğü; merkezileşme, parçalanma ve farklılaşmanın örtüştüğü bir devlettir.” Pers, Roma, erken Bizans, Moğol, Osmanlı, Habsburg, Romanov, Fransız, İngiliz ve Sovyet siyasi yapıları birer imparatorluktur. ${ }^{8}$ Ulus devlet ise meşruiyetini (!) belirli bir coğrafya sınırları içindeki ulustan alan devlet biçimidir. Ulus devlet "ulusallaştırma”yı kendisine hedef edinmiş devlettir. ${ }^{\text {? }}$

İmparatorluklar daima uzun soluklu olmuştur; bunu, müzakereye, yeniden düzenlemeye elverişli yaygın, kalıcı ve esnek örgütlenme tarzlarına borçludurlar. ${ }^{10}$ "İmparatorluğun başarısı, birbirine karşı koyan iki fikrin çözümüne

6 Şevket Süreyya Aydemir, Suyu Arayan Adam, Remzi Kitabevi, İstanbul 2018, ss. 47, 48.

7 Stephen Howe, Imparatorluk, çev.Sinem Gül, Ankara, Dost Kitabevi, 2015, s. 44-45.

8 Alexander J. Motyl, “İmparatorluğu Düşünmek”, Karen Barkey ve Mark Von Hagen (edit.) Imparatorluk Sonrası/Sovyetler Birliği ve Rus, Osmanlı ve Habsburg Imparatorlukları, çev.Ebru Kılıç, İstanbul, Versus Kitap, 2012, s. 38

9 Karen Barkey, “İmparatorluğun Sonuçlarını Düşünmek”, İmparatorluk Sonrası/Sovyetler Birliği ve Rus, Osmanlı ve Habsburg Imparatorlukları, çev.Ebru Kılıç, İstanbul, Versus Kitap, 2012, s. 147.

10 Karen Barkey, Farklııklar Imparatorluğu Osmanlılar/Bir Karşılaştırmalı Tarih Perspektifi, çev.Ebru Kılıç, İstanbul, Versus Kitap, 2011, ss. 24-29. 
dayanmaktadır: Parçalanma ve bütünleşme."11 $\mathrm{Bu}$, fethedilen bölgelerin önce bölünmesi/parçalanması ve sonrasında yönetilmesi demektir. İmparatorluğun başarısının dayandığı bir diğer nokta yönetici sınıfın kendisini sürekli olarak yenileyebilmiş olmasıdır. İmparatorluk “doğası gereği” liyakat usulünü esas almıştır. Roma’da, Bizans'ta ve Osmanlı'da yöneticiler en yetenekli kişiler arasından seçilmiştir. ${ }^{12}$ Çünkü aksi halde imparatorlukların farklılığı yönetebilmesi ve ayakta kalabilmesi mümkün değildir. Aynı şekilde imparatorluklarda farklılıkları tanımaksızın bütünleşme gerçekleşemez. Bu konularda Bizans, Roma İmparatorluğu'nun ${ }^{13}$; Osmanlı her ikisinin (kuşkusuz sadece Roma ve Bizans'ın değil) takipçisi olmuştur. İmparatorluklar yalnızca yönetim yapısı veya usulleri konusunda değil, aynı zamanda sosyo-kültürel anlamda da birbirinden beslenmiştir. Kültürel, bilimsel, ekonomik beslenme ve kaynaşma imparatorlukların güçlü, başarılı veya uzun soluklu olmasında rol oynamıştır. ${ }^{14}$ İmparatorlukların başarısının bir diğer sırrı bürokrasinin esnek yapısıdır. Hem Roma'da hem de Osmanlı'da bu esnek yapıyla karşılaşırız.

"Aziz selefleri gibi Osmanlılar da kendilerine yetki verilmediğinde diş bileyip yabancılaşma gerekçesi bulacak ayrı bir devlet görevlisi ve idareci sınıfı ya da grubu yaratmamışlardı. Bu durum büyük ölçüde, elitlerin imparatorluk bünyesine dahil edilmesi pratiğinin, imparatorluğa aidiyet yönünde teşvik edici unsurlar sunmasından, bunun yanı sıra meşruiyet inşası ile kaynakların dağıtımına katkıda bulunmasından kaynaklanıyordu. Her iki imparatorluk da bürokrasiyi hafif tutmuşlardı. Bu imparatorluklar, ancak çok sonraları, bürokratik mevkilerin genişlemesi ve idarenin mevki beklentisi içinde olan insanlarla dolup taşması sonucu sendelemeye başlamıştı."15

İmparatorlukla kısaca mukayese edeceğimiz ulus devlet mekanizması bilindiği üzere öncelikle Westfalya Antlaşması (1648), daha sonra Fransız Devrimi, Aydınlanma Düşüncesi ve Endüstri Devrimi ile birlikte şekillenmiştir. Öncelikle Fransa'da olgunlaşan ulus devlet, sonrasında Avrupa'ya, Asya'ya ve Afrika'ya yayılmıştır. Habermas’a göre bu devletler üç şekilde gelişmiştir: İlkin "birbirinden ayrı yaşayan etnik grupların barışçı yollarla tek tek devletleşmesiyle değil, komşu bölgelere, soylara, alt-kültürlere, dil ve din topluluklarına sirayet ederek" ortaya çıkmışlardır. İkinci olarak ulus devletler halkların asimilasyonu veya baskı altına alınmasıyla gelişmiştir. Bu aşamada topluluklar

11 Barkey, a.g.e., s. 30

12 Dündar Tașer, "Kanuni devrinde Türkiye'ye gelen Avusturya elçisi Busbeque['in] '[p]adişahın etrafını ve Osmanlı ileri gelenlerini gördüm; bunların içinde mevkiini alın terinden, yeteneğinden, zekasından ve bilgisinden başka bir şeye borçlu olan tek adam yoktu"' dediğini aktarmaktadır. Bu Busbeque'e göre Türklerin önlerine çıkan engelleri aşabilmelerinin sırrıdır. Ziya Nur Aksun, Dündar Taşer'in Büyük Türkiyesi/Osmanlı Devlet Anlayışı, Ötüken Neşriyat, İstanbul 2017, ss. 87-88.

13 Polybius’a göre Roma, başarısını büyük ölçüde monarşiyi, aristokrasiyi ve demokrasiyi bir araya getirebilmesine borçludur. Hardt ve Negri, a.g.e., s. 317.

14 Karen Barkey, Farklılıklar İmparatorluğu, ss. 33; 76, 77; 85-99.

15 Barkey, a.g.e., s. 99. 
homojen olmadığı halde homojenleştirilmeye çalışılmıştır. Üçüncü aşamada ulus devletler etno-milliyetçilikle birlikte daha radikal bir form kazanmıştır. ${ }^{16}$

Buradan da anlaşılabileceği üzere ulus devleti millet ve milliyetçiliği göz önünde bulundurmaksızın anlayamayız. Bazı tarihçiler millet ve milliyetçiliğin izlerini tarihin çok daha eski dönemlerine kadar sürse de, homojen bir millet ve buna dayalı milliyetçilik anlayışı modern çağın icadıdır. "Milletler, devleti yaratmaz (...) tersine, devletler milletleri yaratırlar” diyordu Hobsbawm. ${ }^{17}$ Ulus devlet de homojen bir topluluk, "hayali” bir cemaat olarak milleti yaratmıştır. Bu yaratım politik, entelektüel bir kurgu veyahut mitoloji etrafında şekillenir. Bu kurgu ve mitoloji modern çağa geçişle birlikte ortaya çıkan düzensizliğe bir "düzen” getirme çabasının ürünüdür.

\begin{abstract}
"Bunalımlı düzensizlikle başa çıkmak için, toplumlar, yeni ilkeleri gerçekleştirme ve daha önceki yapıların artık gerçekleştiremediği fonksiyonları icra etme tarzları inşa etmelidirler...Yeniden bütünleştirme ve dengeleme mekanizmaları, geçişi yumuşatıp kolaylaştırabilir'; bu tür mekanizmaların en önemlisi milliyetçiliktir...'Komünal dayanışmayı ve rejimin meşruluğunu sürdürmek için, bir altın çağı yeniden başlatmaya kararlı arındırılmış bir milletin uyanışı etrafında yeni bir mitoloji inşa edilir." ${ }^{18}$
\end{abstract}

Batı'nın ve Batılı ulus devlet anlayışının bize armağanı olan bu mitolojiyi Negri ve Hardt gibi teorisyenler patrimonyal ve mutlakiyetçi devlete bağlamıştır. ${ }^{19}$ Artık kralın ilahi bedeni yerine, ulusun tinsel kimliği toprak ve nüfusu ideal bir soyutlama olarak koyuyordu. Daha doğrusu, fiziksel toprak parçası ve nüfus, ulusun aşkın özünün uzantısı olarak düşünülüyordu. Dolayısıyla, modern ulus kavramı monarşik devletin patrimonyal bedenini miras almış ve onu başka bir biçimde yeniden icat etmiştir...[U]lus, modernliği ve gelişmeyi sağlayabilecek tek ve eşsiz etkin araç olarak savunulmuştur... 'Halk' ulusun kökensel temeli olarak sunulsa da, aslında modern halk kavrayışı ulus-devletin bir ürünüdür ve ancak onun özgün ideolojik bağlamında varlığını sürdürür. ${ }^{20}$

16 Ali Osman Gündoğan, (Erişim: 01 Temmuz 2019). http://www.aliosmangundogan.com/PDF/Makale/ Ali-Osman-Gundogan-Devlet-ve-Milliyetcilik.pdf

17 Andrew Vincent, Modern Politik Ideolojiler, çev.Arzu Tüfekçi, İstanbul, Paradigma Yayıncılık, 2006, s. 424. Devletlerin var olmak için milliyetçiliğe ihtiyaçları yoktur. a.g.e., s. 425. Bu "zorunluluk" ulus devlet ile birlikte ortaya çıkmıştır. Türkiye'de de devlet, "millet" yaratmaya çalışmıştır. Cumhuriyetin kurucu elitleri ulus devlet inşa edebilmek için milliyetçiliğe sarılmıştır. Şerif Mardin ulus devlette bu ideolojinin neredeyse bir "din" olarak benimsenmesi konusunda şu sözleri sarf eder: "Mustafa Kemal'in ...işlediği büyük hatalardan bir tanesi, bir kaynak olarak seküler eğitimin ve bir ideoloji olarak milliyetçiliğin birlikte, İslam'ın yerini alabileceğine, Türkiye Cumhuriyeti’nin bu iki temel dayanağının İslam'ın bütün işlevlerinin yerini doldurabileceğine inanmasıydı". Mardin, "Osmanlı İmparatorluğu”, Imparatorluk Sonrası, s. 177.

18 Vincent, a.g.e., ss. 390, 391.

19 Hardt ve Negri, a.g.e., s. 110.

20 Hardt ve Negri, a.g.e., ss. 111,112; 113-119. 
İmparatorlukta devlet, meşruiyetini toplum dışı bir şeyden alır (Tanrı); aslında ulus devletin de meşruiyet kaynağı toplumun dişındadır (Akıl ve Bilim). Aydınlanma düşüncesinin altını çizdiği “'ulusun egemenliği' kavramındaki ulus ya da 'halk' fiilen var olan halk değildir, Aydınlanmacıların kafasındaki 'muhayyel' halktır ve bu halk bir 'kurgudur.'”21 Aydınlanma Düşüncesi, Fransız Devrimi ve Endüstri Devrimi ile olgunlaşan milliyetçilik ve ulus devlet anlayışı kuşkusuz bazı teorisyenlerin ileri sürdüğünün aksine yalnızca ekonomik nedenlere indirgenemez. Marksist düşünce ulus devleti ve milliyetçiliği kapitalizmin ekonomik mantığı ile izah etmiştir. Bu görüşe göre milliyetçilik "bir burjuva eğlencesi"dir; aslolan da milletlerin çatışması değil, sınıf çatışmasıdır. Devrim, sınıfların, kapitalizmin ve milliyetçiliğin aşılmasını gerektirir. Ancak milliyetçilik tek bir nedene indirgenemez ve Avusturyalı Marksist Otto Bauer'in ileri sürdüğü üzere millet de sinıfların ortadan kalkmasıyla buharlaşamaz. ${ }^{22}$ Aksine Bauer, "Bütün insanların milli kültürel cemaatleriyle bütünleşmesine, milletlerin kendi kaderlerini tayininin tam anlamıyla gerçekleştirilmesine, milletlerin kolektif ruhi (geistig) farklılıklarının geliştirilmesine dikkat çekerek sosyalizmin yayılmasının milli cemaatlerin farklılaşmalarını gerektirdiğini” iddia etmiştir. ${ }^{23}$ Batı tarihinde modern millet kurgusu, ulus devlet ve milliyetçilik doğal olarak kolonyalizme de eklemlenmiştir. Kolonyalizm, milliyetçilik, ırka dayalı astüst ilişkisi kurmacası Batı'nın kendi kimliğini inşa etmek için kullandığı son derece fonksiyonel ideolojik araçlara dönüşmüştür. Avrupa, kimliğini, başkalık yaratarak ve ötekileri kötüleyerek oluşturmuştur. Olumlu bütün nitelikler Batı toplumlarına; olumsuz nitelikler diğerlerine aittir. Batı toplumları "rasyonel"dir, diğerleri "irrasyonel"; Batı toplumları "gelişmiş̧"tir; diğerleri "gelişmemiş”; Batı “çalışkan”dır, Doğu “tembel” vs. Bu Avrupa-merkezci bakış açısı Edward Said'in deyimiyle Şark'ı yaratmış ya da “Şarklılaştırmış”tır. Ne ironiktir ki "eleştirel" düşünce geleneğinin önemli isimleri Marx ve Engels bile bu Avrupa-merkezci zihin setine sahiptir; çünkü onlar Avrupa kolonyalizminin “uygarlaştırma misyonu"nu savunmuşlardır. ${ }^{24}$ Engels'in sözleri bunu daha açılayıcı hale getirebilir:

21 Hüsamettin Arslan, Jöntürkler, Jönkürtler ve Muhafazakarlar/Meçhul Okurla Söyleşiler, Paradigma Yayıncılık, İstanbul 2009, s. 34.

22 Vincent, a.g.e., ss. 392-395.

23 Vincent, a.g.e., s. 395. Aslında sol düşünce milli karaktere doğrudan karşı çıkmamıştır. Hem sol hem de sağ düşünce zaman zaman milliyetçiliğe eklemlenmiştir. Bu bütünleşme ya da eklemlenmelerden de totaliter rejimler doğmuştur. “...Karl Popper’e göre milliyetçilik 'açık toplum'un kurulmasını önleyen en büyük engellerden biridir...” Mehmet Karakaş, “Türkçülük ve Türk Milliyetçiliği”, Doğu Batı, Ankara 2006, Sayı:38, s. 58.

24 Negri ve Hardt, a.g.e., s.138,139; Vincent, a.g.e., s. 393-395. Marx Hindistan'ın Batı toplumlarına benzeyerek ilerleyebileceğini düşünüyordu. Ona göre İngiltere'nin sömürgeciliğinden önce de Hindistan'da savunulacak bir şey yoktu. Negri ve Hardt, a.g.e., ss. 134, 135. 
"Bana göre, uygun koloniler, yani Avrupalı bir nüfus tarafından işgal edilmiş ülkeler -Kanada, Güney Afrika, Avustralya- bağımsız olacaktır. Diğer yandan, yalnızca egemenlik altına alınan yerli nüfusların yaşadığı ülkelerin Hindistan, Cezayir, Hollanda, Portekiz ve İspanyol sömürgelerinin- yönetimi [devrimi takip eden] dönemde işçi sınıfınca ele geçirilmelidir ve bu ülkeler mümkün olduğu kadar hızlı bir biçimde bağımsızlığa kavuşturulmalıdır." ${ }^{25}$

Bu Avrupa-merkezci bakış açısı ve kolonyalizm ulus devletin şekillenmesinde etkili bir rol oynamıştır. Bunların yanı sıra hem neden hem de sonuç olarak görülebilecek milliyetçilik, jakobenizm, 1rkçılık ve emperyalizm de ulus devlet ile bütünleşmiştir. Ulus devlet ırkçıllk, "etnik milliyetçilik"26 hastalığ1na yakalanmış ve bu hastalık dünyaya salgın gibi yayılmıştır. Irkçılık geçmiş imparatorlukların değil, kolonyal imparatorlukların ürünüdür. Örneğin Benedict Anderson'ın da belirttiği üzere on dokuzuncu yüzyıl İngiliz emperyalizmi apaçık şekilde ırkçıdır. ${ }^{27}$ Ancak Batı toplumları kendi tarihlerini aklamak ya da meşrulaştırmak için emperyalizmi ve ırkçılığı zaman zaman geçmiş imparatorlukları ve özelde Osmanlı'yı suçlamak için bir silah olarak kullanmışlardır.

Ulus devlet ile birlikte tarihi yeniden yazanların oluşturduğu Avrupa merkezli tarih anlayışı savaşların ve emperyalizmin sürekliliğini vurgular. $\mathrm{Bu}$ anlayışa göre emperyalizm her zaman varolmuştur. Ancak üniversalist tarih anlayışını savunan Karam Khella'ya göre tarihin her döneminde emperyalizm yoktur. ${ }^{28}$ Fakat Batı, kendini temize çıkarmak için emperyalizmi mesela Osmanlı'ya da teşmil edecek şekilde kullanmıştır. Emperyalizm Latince "imperium” kavramından türemiştir. Bir devletin sömürüye dayalı yayılmacılığını, ele geçirdiği topraklar ve devletlerin kaynaklarını kullanmasını, orada hüküm sürmesini, diktatöryal yönetimini, başka bir milleti, topluluğu kültürel, siyasi, ekonomik olarak egemenlik altına almasını ifade eder. Bu tanımdan hareketle geçmişteki imparatorlukların da emperyalist olduğu savunulmuştur. Ancak Eric Hobsbawm'ın da ifade ettiği üzere emperyalizm kelimesi 1890'lı yıllarda sömürgecilikle gündeme gelmiştir. İmparatorluk eski, emperyalizm yenidir. ${ }^{29}$ Mesela Negri ve Hardt da emperyalizmi "Avrupalı ulus-devletlerin egemenliklerini kendi sınırlarının ötesine yayması” olarak değerlendirmiştir.30 Gerçekten de kavram Marx'ın yazılarında bile geçmez.

25 Vincent, a.g.e., ss. 393-394.

26 “Etnik milliyetçilik’ popülasyonu “imparatorluk” olan ülkeler için kanserojendir.” Arslan, a.g.e., s. 11-12.

27 Benedict Anderson, Hayali Cemaatler/Milliyetçiliğin Kökenleri ve Yayılması, çev.İskender Savaşır, İstanbul, Metis Yayınları, 2004, s. 110.

28 Karam Khella, Tarihin Yeniden Keşfi/ Üniversalist Tarih: Avrupa Merkezci Tarihsel Bilincin Yıkımı, çev. İsmail Kaygusuz, İstanbul, Su Yayınevi, 2005, s. 173-174.

29 Eric Hobsbawm, Imparatorluk Çağı 1875-1914, çev. Vedat Aslan, Ankara, Dost Kitabevi Yayınları, 1999, s. 71.

30 Negri ve Hardt, a.g.e., s. 16. 
Daha sonrasında Lenin, “'emperyalizm[i], kapitalizmin tekelci aşaması” olarak nitelendirmiştir. ${ }^{31}$ Kavram, 1870’lerde kullanılmaya başlamış, 1900’lü yıllarda giderek olumsuz anlamlar kazanmıştır. ${ }^{32}$

Buradan hareketle emperyalizmi Osmanlı'ya teşmil etmenin doğru olmadığını söyleyebiliriz. Emperyalizm sömürgecilik ve ırkçılıkla ilişkilidir ve ayrıca egemenliğin yayılma sürecinde dilin, dinin empoze edilmesini de içerir. Bu nedenle Osmanlı emperyalist olarak değerlendirilemez. ${ }^{33}$

Bütün bunlardan hareketle kısaca imparatorluk ile ulus devlet arasında karşılaştırmalar ve onlar üzerine genellemeler yapabiliriz. Metnin başında da belirttiğimiz üzere imparatorluklar doğası gereği karma, heterojen, her zaman olmasa da genel olarak hoşgörülü iken, ulus devletler homojen, tektipleştirici siyasi birimler olarak değerlendirilebilir. Ulus devletler bazen liberal, bazen gelenekçi veya bütüncü görünümler sergilemişlerdir. Hepsi “çoğulcu demokratik parlamenter sistemi" benimsediklerini iddia etmiştir, ancak bagajlarında taşıdıkları ideoloji milliyetçiliktir. Bu nedenle dayatmacı, baskıcı veya dışlayıcı politikalardan vazgeçememişlerdir. Ulus devletler milliyetçiliğe, ırkçllığa, jakobenizme veyahut başka totaliter ideolojilere saplandıkları ölçüde daha anti-demokratik görünümler sergilemişlerdir. İmparatorluklar çoğu zaman liyakate dayalı sistemler üretmişken, ulus devletlerde yönetim çoğu zaman para oligarşisinin eline geçmiştir. “...[İ]mparatorluklar, [aynı zamanda] topraktan çok halkları, sınır bölgelerinden çok sınırları tanımalarıyla ulus-devletlerden ayrılmışlardır." ${ }^{34}$ Dil ve dolayısıyla düşünce bazında da imparatorluk ulus devlet karşısında daha heterojendir. "İmparatorluk dili he-

31 Howe, Imparatorluk, s. 36.

32 Hobsbawm, a.g.e., ss. 71-72.

33 Batı bu tavrı yalnızca emperyalizm konusunda değil, aynı zamanda kölelik kurumunda da sergilemiştir. Bu bakış açısına göre Osmanlı'daki kölelik Batı'dakine benzer özelliklere sahiptir. Fakat mesela Helmuth von Moltke, Batı'nın Doğu'daki kölelik kurumu hakkındaki fikirlerinin yanlış olduğunu ortaya koymuştur. Örneğin bir Türk kölesiyle Amerika'daki siyahi arasında dağlar kadar fark vardır. Molkte bunu çok daha anlamlı şekilde izah eder: "Hatta bizim bu kelimeye verdiğimiz anlam bile oradakine uymaz. Abd (kul) kelimesi, bizim kullandığımızdan başka manaya gelir. Abdullah (hatta padişahın ismi olan) Abdül Mecid, 'Allah’ın kölesi' demektir. Herhangi bir Avrupa devleti, Doğu'daki bütün esirlerin azad edilmesini sağlasa, esirler bundan asla memnun olmayacaklardır. Daha çocukluğunda velinimetinin (kendisini bakıp besleyenin) evine giren esir, ailenin bir üyesi haline gelir. Yemeklerini evin oğullarıyla beraber yer; ev işlerini onlarla beraber yapar. Bunlar da öyle ağır şeyler değildir. Esirlik, hemen hemen sadece azad edilmekle son bulmaz; esirin bütün ömrü boyunca geçimi de sağlanır. Çoğu zaman köle, evin kızıyla evlenir, eğer evin oğlu yoksa, efendisi onu kendisine mirasçı yapar. Padişahın damadları bile satın alınmış kölelerdir.” Dündar Taşer'den aktaran Aksun, a.g.e., ss.86-87. Dündar Taşer'e göre de “Türk toplumunda, hiçbir zaman diğer sınıflardan ayrılan ve aşağı görülen bir köle sınıfı olmamıştır. Hatta çeşitli sosyal sınıflar arasında, büyük statü farkları da mevcut olmamıştır. Toplumun en aşağı tabakasında olması gereken köle, en yukarı tabakaya çıkabilmiştir. Bunda ise en büyük rolü, yeteneği oynamıştır." Aksun, a.g.e., ss.86-87. Mısır Çarşısı kapıcısının oğlu Ali Paşa'nın sadrazamlığa yükselmesi bunun örneklerinden yalnızca biridir.a.g.e.,s. 88. Bu konu ve İslam dünyası ile Avrupa'daki kölelik arasındaki farklııılar için ayrıca bakınız, Howe, a.g.e., ss. 93-95.

34 Whittaker'dan aktaran Karen Barkey, Farklılılar Imparatorluğu, s. 31. 
terojen, ulus dili homojendir; imparatorluk dili belirsiz, ulus dili kesindir; belirsizlik 'demokratik', 'kesinlik' totaliterdir."35

\section{Sonuç Yerine: Osmanlı ve Türkiye}

İmparatorluk ile ulus devlet karşılaştırmaları, bugünün penceresinden geçmişi yargılama amacı barındırdığı ölçüde problematik veya anakronistik karşılaştırmalar olarak değerlendirilebilir. Çünkü her sistemi, toplumu veya siyasi yapıyı içinde bulunduğu döneme veya çağa göre ele almak gerekir. Ulus devlet savunucuları (özelde Türkiye'de cumhuriyet savunucuları) bugün bakış açıları, kavramları, "doğru”larından hareketle geçmiş imparatorlukları (özelde Devlet-i Aliyye’yi) acımasızca yargılayabilmektedir.

Mesela yukarıda da sözünü ettiğimiz üzere Batı dünyası ve zaman zaman Türkiye'ye Avrupa-merkezci ya da oryantalist bir bakış açısıyla yaklaşan araştırmacılar, teorisyenler, "aydınlar" kavramın kendisi bile henüz kullanımda olmadığı halde Osmanlı’yı "emperyalist” olarak nitelendirmişler, politik, kültürel, ekonomik, bilimsel yapısını insafsızca eleştirebilmişlerdir. Bu eleştirilere göre imparatorluk “kötü”, ulus devlet “iyi”dir; imparatorluk “anti-demokratik”, ulus devlet “demokratik”tir; Osmanlı “teokratik”, ulus devlet “laik”tir; imparatorluk "hukuk-dışı”, ulus devlet "hukuk devleti”dir; vb. Halbuki Halil İnalcık'ın da belirttiği üzere Osmanlı'da şeriat dışında yüzlerce devlet kanunu bulunmaktadır ve imparatorluk bir anlamda hukuk devletidir. ${ }^{36}$ Ayrıca İnalcık'a göre “[i]mparatorluk, bütün dinler, etnik gruplar, cemaatler üzerinde bir egemenlik şemsiyesi olarak kalmış; iç barış ve koruma dışında ortak bir ideolojiyi zorla kabul ettirmek gibi bir siyaseti asla benimsememiştir. Soyut bir değerlendirme yapmak gerekirse, durum imparatorluk rejimi için cidden bir başarıdır." ${ }^{37}$ Ulus devlet ile karşılaştırarak imparatorluğun başarısız olduğunu söylemek en hafif tabirlerle "sığllk", adaletsizlik veya "dar görüşlülük" olabilir. Bugünün penceresinden geçmişi yargılamak kolaydır. Ancak unutulmamalıdır ki gelecek nesiller de ulus devleti, ulus devletin politikalarını, günümüz bilimini, teknolojisini ve uygulamalarını aynı acımasızlıkla eleştirebilir. Aslında adil ve doğru tavır şudur: Ulus devletleri ulus devletlerle, imparatorlukları da diğer imparatorluklarla mukayese etmek veya kendi dönemlerini göz önünde bulundurarak değerlendirmek.

35 Hüsamettin Arslan, Jöntürkler, Jönkürtler ve Muhafazakarlar, s. 140.

36 Halil İnalcık, “Osmanlı Tarihi Üzerinde Kamuoyunu Illgilendiren Bazı Sorular," Makaleler- I, Doğu Batı Yayınları, Ankara 2018, s. 196.

37 İnalcık, a.g.e., s. 207. 
Türkiye'nin kuruluşundan itibaren zihinleri meşgul eden ve günümüzde yeniden tartışma konusu haline gelen meselelerden biri şudur: Türkiye Cumhuriyeti Osmanlı'nın devamı mıdır? Atatürkçü görüş açısından Cumhuriyet radikal bir kırılma veya dönüm noktası; Osmanlı'nın anti-tezi olma niteliği taşır. Buna göre Türkiye Cumhuriyeti Osmanlı'nın devamı olarak görülemez. Aynı görüşe göre Avrupa'nın, Cumhuriyeti bu şekilde algılaması yanlış bir “Türk imajı”nın yaygınlaşmasına sebep olmaktadır. ${ }^{38}$ Fakat bu düşünme tarzı "sıfır noktası"ndan hareketle bir toplum yaratılamayacağını, tarihte mutlak ve büyük kopuşların veya kırılmaların olamayacağını göz ardı ettiği için son derece problemlidir. Hüsamettin Arslan'ın bu konudaki görüşleri çok daha "aydınlatıcı" ve "anlamlı" olabilir:

“Cumhuriyet, kadim Türk(iye) devlet geleneğinde keskin ve radikal bir "hanedan’ değişikliğidir. Meşru Osmanlı hanedanının yerini dönemin iç ve dış konjonktürel koşullarının yardımıyla 'aydınlanmış' modern ve nevzuhur bir elit 'azınlık' zümre almıştır. Devlet form olarak aynı devlettir, geleneğin devletidir. Muhatabı olan halk aynıdır, imparatorluğun bakiyesi halktır. Devletin mekanı aşağı yukarı aynı coğrafyadır, komşu devletler hemen hemen aynıdır. Değişen, devlet formunun muhteva ve içeriğidir. Popüler politik jargonla söylemek gerekirse devletin içeriği yani 'resmi ideoloji'si değiş̧miştir. Cumhuriyet devletimiz "ideokratik" bir devlettir ve rejimi “ideokrasi'dir...Devlet gelenekleri tekil politik faillerin ve 'modern' resmi ideolojilerin aşamayacağı kurumlardır. Diktatörlerin bile gölgelerinin üstünden atlama lüksleri yoktur. Devlet geleneğimiz biz nereye gidersek oraya giden, nereye yönelirsek oraya yönelen, üzerinden sıçrayarak geçemeyeceğimiz gölgemizdir. Devlet geleneğimiz derin Osmanlı'dır, derin Türkiye'dir."39

Buradan hareketle cumhuriyeti ve ulus devleti her konuda meşrulaştırmak ve aklamak için geçmişimizden kaçmanın, onu reddetmenin beyhude bir çaba olduğunu söyleyebiliriz. Aynı şekilde ulus devletlerle birlikte imparatorlukların sona erdiği, günümüz devletlerinin mutlak anlamda ulus devletler olduğu iddiasının da geçerli olmadığını ileri sürebiliriz. Aslında tarihin bize gösterdiği üzere ulus devletler istisna; çok-uluslu devletler kuraldır. Milliyetçilikle boğuşan Avrupa'da bugün hala çok-uluslu devletler mevcuttur. ${ }^{40}$ Türkiye de bugün hala resmi kurumları hasebiyle ulus devlet olsa da, halklarından dolayı "de facto imparatorluk"tur. ${ }^{41} \mathrm{Bu}$ nedenle politik vizyonunu buna göre belirlemek zorundadır.

38 İnalcık, a.g.e., ss. 205-208.

39 Hüsamettin Arslan, “Aydınlanmış Ulus Devletten Demokratik İmparatorluğa”, Kriter Dergi, 03 Aralık 2016, https://kriterdergi.com/dosya/aydinlanmis-ulus-devletten-demokratik-imparatorluga

40 Vincent, a.g.e., s. 426.

41 Arslan, a.g.e., s. 11. 


\section{Kaynakça}

AKSUN, Ziya Nur, Dündar Taşer'in Büyük Türkiyesi/Osmanlı Devlet Anlayışı, Ötüken Neşriyat, İstanbul, 2017.

ANDERSON, Benedict, Hayali Cemaatler/Milliyetçiliğin Kökenleri ve Yayılması, çev. İskender Savaşır, Metis Yayınları, İstanbul, 2004.

ARSLAN, Hüsamettin, Jöntürkler, Jönkürtler ve Muhafazakarlar/Meçhul Okurla Söyleşiler, Paradigma Yayıncılık, İstanbul, 2009.

ARSLAN, Hüsamettin, “Aydınlanmış Ulus Devletten Demokratik İmparatorluğa”, Kriter Dergi, 03 Aralık 2016 (Erişim: 01 Temmuz 2019). https://kriterdergi. com/dosya /aydinlanmis-ulus-devletten-demokratik-imparatorluğa

AYDEMIR, Şevket Süreyya, Suyu Arayan Adam, Remzi Kitabevi, İstanbul, 2018.

BARKEY, Karen, “Imparatorluğun Sonuçlarını Düşünmek”, Karen Barkey ve Mark von Hagen (edit.), Imparatorluk Sonrası/Sovyetler Birliği ve Rus, Osmanlıve Habsburg Imparatorlukları, çev. Ebru Kılıç, Versus Kitap, İstanbul, 2012, ss. 141-161.

BARKEY, Karen, Farklılılar İmparatorluğu Osmanlılar/Bir Karşılaştırmalı Tarih Perspektifi, çev. Ebru Kılıç, Versus Kitap, İstanbul, 2011.

GÜNDOǦAN, Ali Osman, “Makaleler”, (Erişim: 01 Temmuz 2019). http://www.aliosmangundogan.com/PDF/Makale/Ali-Osman-Gundogan-Devlet-ve Milliyetcilik.pdf

HARDT, Michael ve NEGRI Antonio, İmparatorluk, çev. Abdullah Yılmaz, Ayrıntı Yayınları, İstanbul, 2018.

HOBSBAWM, Eric, İmparatorluk Çağı 1875-1914, çev. Vedat Aslan, Dost Kitabevi Yayınları, Ankara, 1999.

HOWE, Stephen, İmparatorluk, çev. Sinem Gül, Ankara, 2015.

INALCIK, Halil, "Osmanlı Tarihi Üzerinde Kamuoyunu Ilgilendiren Bazı Sorular," Makaleler- I, Doğu Batı Yayınları, Ankara, 2018.

KARAKAŞ, Mehmet, “Türkçülük ve Türk Milliyetçiliği”, Doğu Batı, Doğu Batı Yayınları, Ankara, 2006, Sayı:38, ss. 57-76.

KHELLA, Karam, Tarihin Yeniden Keşfi/ Üniversalist Tarih: Avrupa Merkezci Tarihsel Bilincin Yıkımı, çev. İsmail Kaygusuz, Su Yayınevi, İstanbul, 2005.

KURTDAŞ, Muzaffer Çağlar, “Küresel Terör Çağında Ulus Devletin Artan Önemi," TESAM Akademi Dergisi, Bursa 2018, Sayı:5(2), ss. 151-181.

MARDiN, Şerif, "Osmanlı İmparatorluğu”, Karen Barkey ve Mark Von Hagen (edit.) Imparatorluk Sonrası/Sovyetler Birliği ve Rus, Osmanlı ve Habsburg Imparatorlukları, çev. Ebru Kılıç, Versus Kitap, İstanbul, 2012, ss. 163-179.

MOTYL, Alexander J., “imparatorluğu Düşünmek”, Imparatorluk Sonrası/Sovyetler Birliği ve Rus, Osmanlı ve Habsburg İmparatorlukları, çev. Ebru Kılıç, Versus Kitap, İstanbul, 2012, ss. 35-49.

VINCENT, Andrew, Modern Politik İdeolojiler, çev. Arzu Tüfekçi, Paradigma Yayıncılık, İstanbul, 2006.

YILDIRIM, Ergün, “Küreselleşen Dünyada Milliyetçilik,” Doğu Batı, Ankara, 2006, Sayı:38, ss. 181-199. 


\title{
Çokkü̈ltürllülük Tezi Kontekstinde İngiltere Kolonyalizmi: Beyaz Verem Salgını*
}

\author{
Akif Kemal Koç**
}

Öz

Sosyal bilimlerin ilgi alanına giren neredeyse tüm disiplinler ve konular varlıklarını coğrafi keşiflere, onu takip eden kolonyalizme, Aydınlanma felsefesine ve bunu takip eden devrimlerle birlikte modernleşmeyle ilişkilidir. Sosyolojinin arka planında da coğrafi keşifler, sömürgecilik, hümanizm, Aydınlanma düşüncesi, Fransız Devrimi, kentleşme, göç ve Sanayi Devrimi vardır. Sosyoloji bütün bunların beraberinde getirdiği "insan sorunu”ndan doğmuştur. Kolonyalizm modern çağda “insan sorunu”nu başta Avrupa'nın, daha sonrasında bütün dünyanın gündemine taşıyan gelişmelerden biridir. Batı başlangıçta kolonyalizmi homojenleştirme politikalarıyla sürdürmüştür. Önce Amerikan kolonilerinin, daha sonrasında Hindistan ve Güney Asya kolonilerinin bağımsızlığını kazanmasıyla birlikte kolonyalizm tartışmaları çokkültürlülük tezi ile yeniden gündeme gelmiştir. Çok kültürlülük Batı kolonyalizminin bir ürünüdür. Bu çalışmada şu iddia temellendirilmeye çalışılacaktır: Homojenleştirme politikaları problemlidir, ancak çokkültürlülük söyleminin de birtakım açmazları vardır. Yine de toplumların ve dünyanın homojenleştirilmesi karşısında çokkültürlülük söylemi daha anlamlı ve tercih edilebilir bir söylem olarak görülebilir.

Anahtar Kelimeler: Kolonyalizm, Britanya İmparatorluğu, Sömürgecilik, Amerika, Kanada, Hindistan.

\section{British Colonialism in the Discourse of Multiculturalism: The White Plague}

\section{Abstract}

Almost every discipline and subject, which are within social sciences' area of interest owe their existence to the geographical discoveries, colonialism which follows geographical discoveries, philosophy of enlightenment, and the following revolutions and modernization. In the background of sociology are geographical discoveries, colonialism, humanism, thinking of Enlightenment, French Revolution, urbanization, migration, and Industrial Revolution. Sociology arised from the "human problem" that all together had brought about. Colonialism is one of the developments that brought the "human problem" to the agenda of Europe in the first place and then the whole world in the modern age. The West originally maintained colonialism through homogenization policies. A multicultural rhetoric began to develop in colonial debates, after American colonies in the first place and then the Indian and South Asian colonies gained independence. Multiculturalism is a product of Western colonialism. This study will try to discuss the claim that homogenization politics are problematic, but multiculturalism also has a number of dilemmas. Nevertheless, the discourse of multiculturalism can be seen as a more meaningful and preferable discourse compared with the discourse of the homogenization of the societies and the world.

Keywords: Colonialism, British Empire, Colonial System, America, Canada, India.

*"Beyaz Verem Salgını” başığını Britanya İmparatorluğu'nun kolonyalizminin detaylı bir tarihsel incelemesini yapan Niall Ferguson'dan ödünç alıyorum. Ferguson'un İngiltere'den diğer kıtalara yerleşmek üzere göç ederek ayrılan milyonlarca insan için bu başlığı kullanmayı tercih etmiş olması İngiltere'nin yayılmacılığının boyutlarını özetlemek için yeterlidir. Ferguson, Niall, İmparatorluk: Britanya'nın Modern Dünya'yı Biçimlendirişi, çev.: Nurettin Elhüseyni, İstanbul, Yapı Kredi Yayınları, 2013, ss. 71-122.

**Doktora Öğrencisi | Sakarya Üniversitesi, Sosyal Bilimler Enstitüsü | akifkemalkoc@gmail.com ORCID: 0000-0003-4557-2953 | DOI: 10.36484/liberal.606175

Liberal Düşünce Dergisi, Yıl: 24, Sayı: 95, Yaz 2019, ss. 99 - 109. Gönderim Tarihi: 19 Ağustos 2019 | Kabul Tarihi: 28 Ağustos 2019 


\section{Giriş̧}

Kolonyalizm, günümüz çokkültürlülük tartışmalarının en temel sebeplerinden birisidir. Zira kolonyalizm süreci ile Avrupa medeniyetinin Afrika'ya, Amerika'ya ve Güney Asya'ya ihracının ve oradaki ulusların Avrupa merkezci bir perspektiften yeniden inşa edilmesi ve sömürülmesinin neticesinde yüzlerce yıl sürecek yeni problemler doğmuştur. Amerika'daki İngiliz kolonilerinde plantasyonlarda çalıştırılmak üzere getirilen kölelerin, Amerikan İç Savaşı'ndan sonra özgürleşmesi ve yirminci yüzyllın tamamı boyunca eşitlik yönündeki hak talepleri buna örnek gösterilebilir. Bunun yanında kolonilerin bağımsızlık kazanmasından sonra Avrupa'ya koloni ülkelerinden göç eden göçmenlerin sorunları ve hak talepleri ve homojenleştirme politikasının başarısızlığı bugün çokkültürlülük tartışmalarının sebepleri arasında gösterilebilir. Benzer biçimde Amerika'nın İngiltere'den bağımsızlığını takip eden göçler neticesinde kozmopolit bir ulusa dönüşmesi de çokkültürlülük kavramının ortaya çıkmasının temel sebepleri arasında sayılabilir. Dolayısıyla modern imparatorlukların gerçekleştirdiği kolonyalizm realitesi anlaşılmaksızın çokkültürlülük anlaşılamayacaktır. Bu nedenle, bu çalışmada kolonyalizm faaliyetini dünyanın dört bir yanında gerçekleştiren İngiliz kolonyalizmi incelenecektir.

Çalışmanın kapsamı gereği İngiliz kolonyalizmi sınırlı bir çerçevede sunulacaktır. Zira kolonyalizm tartışması çok geniş bir literatürü kapsamaktadır. Yine çokkültürlülük tartışmaları da kapsamlı bir literature sahiptir. Bu nedenle elinizdeki metin çokkültürlülük tartışmalarını da dar bir perspektiften, İngiliz kolonyalizmi üzerinden tartışmayı deneyeccektir. İlkin İngiliz kolonyalizminin kısa bir tarihçesi verilecektir. Burada kolonyalizm ve İngiltere'nin yayılmacı politikasının homojenleştirme fikriyle de yakından ilişkili olduğu vurgulanacaktır. Çalışmanın ilerleyen kısmında İngiliz kolonyalizmi ile çokkültürlülük tezinin organik bağı tartışlacaktır.

Günümüz çokkültürlülük tezi etnisiteye dayalı problemlere bir çözüm olarak sunulmuş, fakat bunun "kolonyalizm" ile olan bağı sürekli olarak gözardı edilmiştir. Halbuki kolonyalizm klasik "imparatorluklar" ın değil, modern "imparatorluk"ların fiilidir. ${ }^{1}$ Dolayısıyla çokkültürlülük tezi kolonyalizm ile birlikte değerlendirilmelidir. Çünkü İngiliz kolonyalizmi yalnızca ekonomik bir temel üzerine inşa edilmemiştir. Ekonomik sebeplerin yanında Anglo-Sakson Protestan beyazların ağırlıkla idarede olduğu kolonilerle yerlile-

1 Bilindiği gibi "Modernite" Rönesans ve Reform ile 17. Yüzyılda ortaya çıkmıştır. Dolayısıyla modernitenin ortaya çıkışı ile dünyanın geri kalanının "beyaz Avrupalılar" tarafından sömürülmesi ve zulme maruz bırakılması, modernitenin insan anlayışı ile yakından ilgilidir. Aydınlanma düşüncesiyle birlikte Tanrı'nın iradesini insana vermiştir. Kolonyalizm homo rationalis'in eylemidir ve bu yönüyle moderndir. 
rin Britanya'nın çıkarları için medenileştirilmesi ve alt ırklardan müteşekkil homojen İngiltere'lerin kurulması amaçlanmıştır. Bunun somut sonucu ise, "medenileşemeyen" ya da direniş gösteren yerlilerin sistematik bir şekilde yok edilmesi ya da kültürel, dini asimilasyona uğratılmalarıdır.

\section{İngiltere Kolonyalizmi: Beyaz Verem Salgını}

"Aslanlar kendi tarihçilerine sahip olana kadar, avın tarihi avcıyı övecektir"

\section{Chinua Achebe}

"And Englishmen like posing as gods/Ve Ingilizler Tanrılar gibi tavır takınmayı severler."

E.M. Forster ${ }^{2}$

"Yoktur savaşma derdimiz,

Ama vallahi bu gerekse bile,

Kendimiz gitmeyiz cepheye,

Uysal Hinduları göndeririz." ${ }^{3}$

\section{W.E. Forster}

Kolonilerin bağımsızlık dalgasının başlamasının ardından geçen onlarca senenin ardından İngiliz kolonyalizminin sömürge toplumlarındaki gelişmeye yönelik etkileri üzerine tartışmalar hala devam etmektedir. Neoliberal tez, Britanya'nın sömürge ülkeleri üzerindeki hükmünü olumlamaktadır, dolayısıyla bu tezin göz ardı ettiği şeyler de eleştiri konusu olmuştur. ${ }^{4}$ Neoliberal teze göre Britanya İmparatorluğu kolonyalizm vasıtasıyla dünyanın birçok bölgesine uygarlığın nimetlerini taşımıştır. Buradan hareketle birçok tarihçi, liberal politik ve ekonomik kurumları hızla yaygınlaştırdığını ve gelişimi motive ettiğini öne sürerek İngiliz kolonyalizmini olumlamaktadır. ${ }^{5}$ Bunun sonucunda koloni devletleri bugün hiç olmayacakları kadar iyi duruma gelmiştir.

Fakat bu görüş kölelik tecrübesini, kitlesel açlıkları, koloniler için verilen savaşları, etnik ayrımcılıkları ve yerlilerin İngiltere'ye ekonomik bağımlılıkları gibi birçok sorunu atlamaktadır. Kolonicilerin bir devlet politikası olarak yeni bölgelere sistematik göçü, zorunlu bir göç değildir. Aslında bu göç hareketinin amacı gidilen bölgelerde yeni İngiltereler kurmak olarak görülebilir. Yeni İngiltereler kurulurken yerlilerin katledilmesi ve topraklarının İngiliz göçmenler tarafından iskan edilmesi de yine Britanya'nın kolonyal hükmünün diğer uluslarda gelişmeye sebep olduğu tezini savunanların atladığı bir başka

2 Edward Morgan Forster, A Passage To India, Penguin Classics, Cambridge 2005, s. 45.

3 Ferguson, Niall, Imparatorluk: Britanya'nın Modern Dünya'yı Biçimlendirişi”, çev.: Nurettin Elhüseyni, İstanbul, Yapı Kredi Yayınları, 2013, s. 174.

4 Matthew Lange, Lineages of Despotism and Development: British Colonialism and State Power, University of Chicago Press, Chicago 2014, s. 1.

5 Lange, a.g.e., s. 1. 
önemli noktadır. Zira bugün Güney Afrika Cumhuriyeti'nin, Yeni Zelanda’nın ve Avustralya kıtasının ve Kuzey Amerika'nın bütünüyle beyaz Anglo-Sakson'lardan oluşması buradaki yerli halkların tamamıyla katledilmesinin neticesidir. ${ }^{6}$

1500’lü yıllarda İspanya ve Portekiz krallıkları Güney Amerika kıtasında nasıl sistematik sömürgeleştirme politikaları uygulamış ve katliam yapmışsa, ${ }^{7}$ 1600'lü yılların sonuna gelindiğinde de İngiltere'nin kurduğu kolonilerle, Kuzey Amerika'da da aynı katliamlar vuku bulmaya başlamıştır. Bu katliamların gerçekleştirilmesinde bugün çokkültürcülük tezinin yoğun eleştiriye tabii tuttuğu evrensellik iddiası ve İngiltere'nin gerek kültürel gerekse ekonomik bakımdan diğer ulusları homojenleştirme politikası etkili olmuştur. Elbette buradaki homojenlik iddiası aynı değerleri ve kültürü paylaşan beyazların homojenliğidir ve yerlilere bu kontekstte sınırlı ölçüde müsamaha gösterilmiştir. Mesela Amerikan yerlilerine İngiltere'nin ekonomik çıkarlarına hizmet ettikleri ve uyum sağladıkları ölçüde göreceli bir hoşgörü politikası uygulanmıştır. ${ }^{8}$ Ancak yerliler kolonyal çıkarlar için sistematik şekilde yok edilmeye devam etmiştir. İngilizlerin Kuzey Amerika yerlilerine uyguladıkları yok etme ve göç ettirme politikası yerlilerin kültürel, ekonomik ve siyasi olarak azınlık konumuna düşmelerine kadar sürmüştür. Niall Ferguson'un da belirttiği üzere İspanya ve Portekiz İmparatorluklarının Güney Amerika yerlilerine uyguladığı zulmü İngiltere farklı bir formda gerçekleştirmiştir:

“Daha önce Orta Amerika’da yaşananlar şimdi Atlas Okyanusu’nun kuzey kıyı şeridinde tekrarlanmaktaydı. İngiliz Kuzey Amerikası’na dönüşen kesimde 1500 yılında aşağı yukarı 560 bin Amerikan [y]erlisi vardı. Bu sayı 1700’e doğru yarının da altına indi. Beyaz yerleşim alanlarının batıya doğru yayılmasıyla bütün Kuzey Amerika kıtasını etkileyecek olan çarpıcı gerilemenin daha başlangıcıydı bu... '[Yerli] [K]ayıpların sebeplerinden biri silah bakımından daha donanımlı göçmenlerle kısa ama kanlı savaşlardı. Povhatanların

6 Britanya kolonyalizminin Avustralya'da uyguladığı politikalar bu noktada paradigmatik bir öneme sahiptir. Amerika'daki kolonilerin İngiltere ile giriştikleri savaştan galip çıkmalarının ardından 1783 yılında İngiltere çok fazla sayıya ulaşan mahkumları göndermek üzere Avustralya'yı işgal etmiştir. Avustralya yerlilerinin sistematik biçimde yok edilmesini ve sürgün edilmesini izleyen yaklaşık 150 yıllık süreç içerisinde yerliler diğer kolonilere sürgün edilmiş ve bu sırada milyonlarca İngiliz, İskoç ve İrlandalı da benzer biçimde Avustralya'ya yerleştirilmiştir. Jeremy Bentham'ın mahkumları kontrol altında tutmak ve beyazlardan müteşekkil bir commonwealth inşa etmek üzere panoptikon modelini bulması da bu döneme tekabül eder. İlerleyen dönemde mahkum olarak Avustralya'ya getirilen Britanyalılara, çalışmaları şartıyla toprak ve yerleşim hakkı verilmiş ve böylelikle yerliler 1800 'lü yılların sonuna kadar neredeyse bütünüyle yok edilmiştir. İngiltere'nin Avustralya'yı iş̧gali için bakınız; Sue Ballyn, "The British Invasion of Australia. Convicts: Exile and Dislocation" Lives in Migration: Rupture and Continuity, Australian Studies Centre University of Barcelona, Spain 2010, ss. 16-30.

7 İspanya İmparatorluğunun bütünüyle yok ettiği Aztek ve İnka medeniyetlerinin, sömürgeleştirme ve sistematik biçimde yok edilme süreci hakkında detaylı bilgi için bkz; Bartolomeo de Las Casas, Yerliler'in Gözyaşları: Yerlilerin Yok Edilişinin Kısa Tarihi, çev. Oktay Etiman, Ankara, İmge Kitabevi, 2014.

8 Ferguson, a.g.e., s. 81. 
1622'de Jamestown'a saldırmasından sonra, kolonicilerin görüşleri sertleşti. Sir Edward Coka’a göre Yerliler ancak pertui enimici, yani "ebedi düşmanlar” olabilirdi. "Zira iblis tebaasından olan onlar ile Hıristiyanlar arasında ebedi bir husumet vardır ve asla barış olamaz.' Sırasıyla Povhatan 1623 ve 1644'te, Pekvotlar 1637'de, Doegler ve Suskihannoklar 1675'te, Vampanoaglar 167677'de katledildi." ${ }^{9}$

Şüphesiz İngiliz Kolonyalizminin bugünkü çokkültürlülük tartışmalarında Amerika merkezli etkisi kolonyal Amerika döneminde yapılan yerli katliamları ile sınırlı değildir. 1776'da Britanya'dan bağımsızlığını kazanan Amerikan kolonilerinin kurduğu Amerika Birleşik Devletleri de Kızılderilileri yok etmeye ve toprakların, farklı uluslardan gelen yeni göçmenlere açılması politikasına devam etmiştir. Amerika Birleşik Devletleri, on dokuzuncu yüzyıldan itibaren aldığı göçlerle başlıca Kızılderililer, Britanya’lılar, Fransızlar, İtalyanlar ve Çinlilerden oluşan karma nüfusa sahip bir ulus olarak karşımıza çıkar. Bu nedenle çokkültürlülük tartışmaları ve kültürel çeşitlilik kontekstinde paradigmatik bir öneme sahiptir. ${ }^{10}$

Çokkültürlülük kavramının ortaya çıkışında sömürgeciliğin ve özelde İngiltere kolonyalizminin önemli rolü şüphesiz tarihin en büyük kitlesel göç hareketinin İngiltere tarafından gerçekleştirilmiş olmasında saklıdır. İngiltere kolonyalizmi örneğinde değerlendirildiğinde kolonyalizm ve göç aynı anlamı taşımaktadır. Gerçekten de İngiltere'nin yayılmacı politikası neticesinde milyonlarca insan dünyanın batısında ve doğusunda kurulan kolonilere göç etmiştir. Bugün Avrupa'ya ve Amerika'ya eski sömürge ülkelerinden göç hareketi de kolonyal dönemin bir mirasıdır. İngiltere'den kolonilere göç hareketi devlet politikası olmasının yanında göçmenin de ekonomik çıkarlar sağlayacağını düşünerek gerçekleştirdiği bir eylemdir. Bu noktada göçmen ve kolonyalist arasında bir ayrım yapmak gereklidir. Günümüz kontekstinde kırdan kente ya da eski sömürge ülkelerinden Avrupa ve Amerika'ya göç ile kolonilere göç ve İngiltere'den kolonilere gerçekleştirilen göç birbirinden son derece farklı anlamlara sahiptir. "Kolonyalist olmak sömürgecinin doğal eğilimidir" ${ }^{11}$ ve İngiltere'den kolonilere göç de bu manada yerlilerle birlikte yaşama arzusunun değil, bilakis onları sömürme ve yeni çıkarlar arayışının eseridir. Zira göçmenler açısından değerlendirildiğinde “...yaşamını sömürgelerde geçirmeye karar vermek...en azından çoğu durumda, kötü bir

9 Ferguson, a.g.e., s. 82.

10 Mustafa Şan ve Kemal Haşlak, "Asimilasyon ile Çokkültürlülük Arasında Amerikan Anaakımını Yeniden Düşünmek”, Akademik Incelemeler Dergisi, Sakarya 2012, Sayı: 1, ss. 32-33.

11 Albert Memmi, Sömürgecinin ve Sömürgeleştirilenin Portresi, çev. Şen Süer, İstanbul, Versus Kitap, 2014, s. 62. 
işarettir. Başlangıçta her şeyi kabul etmeye hazır göçmen, sömürgenin fırsatlarından faydalanmak gibi net bir amaçla geldikten sonra, eğilimi gereği sömürgecilik yandaşı olacaktır." ${ }^{2}$

On yedinci yüzyılın ilk yarısından on dokuzuncu yüzyılın sonlarına dek o dönemin bilinen dünyasının dörtte birini yöneten ve hakimiyetini okyanuslarda elde ettiği hegemonyaya borçlu olan Britanya İmparatorluğu, tüm zenginliğini ve ihtişamını kolonilerine ve sömürgeleştirme faaliyetlerine borçludur. İngiltere’nin, sömürgeciliğe, bilhassa Amerika kıtasında, İspanyol ve Portekiz İmparatorluklarına nazaran geç başlamış olduğu halde daha kalıcı koloniler elde etmesinin ardındaki temel sebep Kuzey Amerika'da, yerlilerin daha seyrek nüfusa sahip olmalarıdır. Bunun yanında İngiltere'de deniz ötesi göçe yönelik baskılar daha kuvvetlidir. Çünkü kolonilerden kalıcı kazançlar elde etmek ve sömürgenin devamlılığı için kolonilere daimi bir nüfus akışı olması gerekiyordu. Dolayısıyla göçü teşvik etmek amacıyla kolonilerde kalıcı yerleşim kuran göçmenlere toprak verme politikası uygulanmıştır. ${ }^{13} \mathrm{Bu}$ ve bunun gibi uygulamalar diğer İngiliz kolonileri olan, Yeni Zelanda, Nijerya, Avustralya, Hindistan ve Güney Doğu Asya'da da karşımıza çıkar. Bütün bunlar, göçmenlerin, elde ettikleri toprakları kaybetmemek için yerlileri yok etmesiyle sonuçlanmıştır. Yerliler “[s]unulan 'uygarlığı' reddettikleri ölçüde, toprağa aç çiftçiler onların kökünü kurutma hakkını kendilerinde gördüler. Kıtayı gezip gören bir donanma cerrahına göre, 'vahşi hayvanlardan üstünlükleri mızrak kullanmaktan, aşırı gaddarlığa başvurmaktan ve yiyeceklerini hazırlarken ateş yakmaktan ibaretti." 14 İngiltere Kolonyalizmi sömürge ülkelerine, "uygarlık" maskesi altında soykırım ve post kolonyal dönemde devam edecek olan iç savaş ve daha fazla kıyımdan başka bir şey bırakmamıştır. "Beyaz Verem Salgını" Avustralya'dan Afrika ve Amerika’ya kadar her yere yayılmıştır.

İngiliz kolonyalizminin Hindistan üzerindeki kısa tarihçesini çıkarmak gerekirse, kolonyalizme dair ilk somut adımın Doğu Hindistan Ticaret Şirketi aracılığıyla atıldığını görülmektedir. ${ }^{15}$ Hindistan'ın ve Doğu Asya’nın sömürgeleştirilme süreci Parekh'in ifadesiyle “yavaş, sinsi ve önceden tasarlanmamış bir fetihtir. Doğu Hindistan Şirketi, yabancı bir hükümetten ziyade ticari bir şirket olarak önderlik ederek, iyi davranış sözü vererek ticari çıkarlar uğruna Hindistan’a geldiğinde, özellikle İmparatorluğun çevre kesiminde

\footnotetext{
12 Memmi, a.g.e., s. 62.

13 J. H. Elliott, Empires of The Atlantic World: Britain and Spain in America1492-1830, Yale University Press, New Haven 2006, s. 53.

14 Ferguson, a.g.e., ss. 118-119.

15 Azmi Özcan, “İngiliz Sömürgeciliğinin Doğuşu ve Aşamaları”, Sömürgecilik Tarihi (Afrika- Asya), ed. Azmi Özcan, T.C. Anadolu Üniversitesi Yayını No:3120, Eskişehir, 2014, s. 62.
} 
olmak üzere, Babür hakimiyetinin "erozyon"unundan faydalanmıştır."16 İngiltere'nin Hindistan ve Doğu Asya'daki sömürgecilik faaliyeti Hindistanlıların daha önce tecrübe etmedikleri türden bir işgaldir. Daha önceki işgalciler bu denli kalıcı ekonomik ve demografik sorunlara sebep olmamıştır. Ancak İngiltere, Doğu Hindistan Şirketi'nin ekonomik ve askeri gücünü kullanarak bölgede siyasi ve ekonomik destabilizasyona dayalı bir politika izleyerek yüzyıldan fazla sürecek bir sömürünün zeminini hazırlamıştır. ${ }^{17}$ Ancak hem kültürel olarak köklü bir medeniyete sahip olmaları hem de İngiltere'nin göç vasıtasıyla demografik yapıda değişiklik yapmasına engel teşkil eden yoğun bir nüfusa sahip olması İngiltere'nin Hindistan'daki kolonilerinde Amerika örneğinden farklı politikalar izlemesine sebep olmuştur. Burada izlenilen politika çoğunlukla kültürel ve dini asimilasyona dayalı biçimde Hindistan'ı bir commonwealth ülkesi yapmaya yöneliktir. ${ }^{18}$

İngiltere kolonyalizminin yüzyıllar süren serüveni, nihayetinde on dokuzuncu yüzyılın sonlarına gelindiğinde kolonilerin bağımsız olmalarına ve bununla birlikte yeni modern sorunların ortaya çıkmasına sebep olmuştur. Kolonyal mirasın en önemli sonuçları, Kuzey Amerika Kıtası'nda çokkültürlü bir yapının ortaya çıkması, Asya'da ve Afrika'da ise günümüze kadar sürecek olan siyasi istikrarsızlık ve etnisite problemleridir. Sömürgeciliğin doğası gereği Avrupa merkezci bir perspektiften hareketle sarıldığı, Aydınlanma Düşüncesi veya “Proje"si ile de bağlantılı evrensellik iddiasının ürünü olan yayılmacılık politikasının, faaliyetinin ve homojen bir toplum yaratma projesinin sonucunda yerliler kültürel ve dini asimilasyona uğratılmış ya da bütünüyle yok edilmiştir.

Örneğin Amerika Birleşik Devletleri, bağımsızlığın hemen ardından İngiltere'den aldığı kolonyal miras ile asimilasyona ve uyuma dayalı bir politika izlemiştir.

“...Amerika’nın kendi uluslaşma sürecini tamamladıktan sonra büyük oranlarda göçmen kabul etmeye başladığı dönemden itibaren Amerika'nın birçok kurucusunun, göçmenlerin bir sıfır noktasında olmadıklarına, burada var olan kültürel yapıya entegre olarak asimile olmalarının gerekliliğine sürekli vurgu yaptıklarını görmekteyiz. Bu anlamda Amerikan değerlerinin bir noktada uzlaşma zeminine dayanması gerektiği vurgulanmaktadır. Bu

16 Bhikhu Parekh, “Indian Conceptualization of Colonial Rule”, Colonialism and Its Legacies, ed. Jacob, T. Levy, Lexington Books, Maryland, 2011, s. 157.

17 Parekh, a.g.e., s. 158.

18 Hindistan'ın Hıristiyanlaştırılması ve kültürel asimilasyon politikaları İmparatorluğa bağlı bir Hindistan ile Britanya'nın Doğu ve Güney Asya üzerinde bir hakimiyet kurma projesinin bir tezahürüdür. Hindistan'ın Hıristiyanlaştırılması ve kültürel asimilasyonuna dair detaylı bir anlatım için bakınız; Ferguson, a.g.e., ss. 149-157. 
değerler de Amerika'yı ilk kez koloni yapan İngiltere'nin Anglo-Sakson ve Protestan değerleri olacaktır."19

\section{Sonuç Yerine: Beyaz Verem Salgınının Yaralarını Sarmak: Çokkültürlülük Tezi}

Avrupa merkezcilik, Fransız Devrimi ile yayılan milliyetçilik ve sömürgecilik, homojen bir toplum ve dünya yaratma ideali ile ilişkilidir. Homojen bir toplum yaratma fikri ise, modern çağın ve özelde Aydınlanma düşüncesinin “doğa yasası" ya da yasalarına, ${ }^{20}$ "evrensellik" fikrine bağlılığıyla ilişkilendirilebilir. Epistemolojide, sosyal bilimlerde evrensellik düşüncesinin çok uzun zamandır sarsıntıya uğradığı bilinmektedir. Örneğin perspektifçilik kontekstinde evrensellik fikrinin nasıl eleştirilebileceğini şöyle ortaya koyabiliriz:

"Perspektifçilik, bilimi Gerçekliği doğrudan görmenin eşsiz yolu sayan pozitivizmin tersine, şunu diyor: Her epistemik girişim -ki buna bilim de dahildir- kendi entelektüel ve siyasal bağlılık ve çıkarları tarafından tanımlanan bir bakış açısından doğar. Perspektifçiliğe göre biz, bırakın bütün Gerçekliği, hiçbir şeyi “doğrudan” göremeyiz. Her görme, belli bir perspektiften görmektir. Hatta doğa bilimlerinde bile teorik ve kültürel bakış açılarının etkisi bugün artık sorgulanamayacak biçimde açık görünmektedir."21

Doğa bilimlerinde ve her epistemik girişimde kültürel bakış açılarının izi varsa ve her bilgi iddiası sosyal ve tarihsel ise nasıl evrensel olabilir? Bilgide, bilimde, medeniyette, siyasette evrensellik iddiası Batı merkezli bir medeniyet anlayışının ulaşılması gereken en doğru ve nihai tek istikamet olduğu görüşünü de beraberinde getirmiş ve bununla sömürgecilik meşrulaştırılmıştır. Ancak nihayetinde sömürgeciliğin açtığı yaralar ve dünyanın her tarafında baş gösteren kültürel, etnik ve siyasi problemler sömürgeciliğin yeniden tartışmaya açılmasını sağlamıştır. ${ }^{22}$

19 Şan ve Haşlak, a.g.m., s. 36.

20 Mekanik evren anlayışı ve insanın da mekanik bir varlık olduğu tezi, insanın ölçülmesinin ve ırk kavramı kontekstinde üst-insan ve köle-insan ayrımının da temel sebebidir. Bu fikrin de sömürgeci devletlerin yerlilere yönelik politikalarına etkisi kaçınılmazdır. Doğanın meşru ve değişmez bir yasası olduğu fikri özellikle “...[D]oğadaki çatışmanın insanın da doğasında olduğunun kabul edilmesiyle ırkçılık, faşizm, komünizm, emperyalizm adına yapılan çatışmalar, güçlü milletlerin zayıf gördükleri milletleri ezerek yok etmeye çalışmaları artık bilimsellik kisvesine bürünmüş oluyordu. Barbarca katliamlar yapanlar, insanlara hayvan gibi davrananlar, milletleri birbirlerine düşürenler, ırklarından dolayı insanları hakir görenler, haksız rekabetle küçük işletmeleri kapattıranlar, fakirlere yardım elini uzatmayanlar artık kınanmayacak veya engellenemeyecekti. Çünkü onlar bunu "bilimsel" bir doğa kanununa uyarak yapıyorlardı." Hasan Yaylı, "Mekanik Düşünceden Ekolojik Düşünceye: Yeni Bir İnsan-Doğa İlişkisi Tasarımının Doğuşu”, Sosyoloji Konferansları Otuzdördüncü Kitap, Ed., İstanbul Üniversitesi Yayınları, İstanbul, 2006. S. 76

21 Brian Fay, Çağdaş Sosyal Bilimler Felsefesi: Çokkültürlü Bir Yaklaşım, çev. İsmail, Türkmen, İstanbul, Ayrıntı Yayınları, 2017, ss. 12-13.

22 Batı'nın sömürgeleştirdiği uluslar üzerindeki üstünlük iddiası ve bunun çarpıcı sonuçlarına örnek 
Yukarıda sözü edilen evrensellik fikrinin idare etme, iskan etme ve "medenileştirme" politikalarında da çöktüğü ortadadır. Yukarıda bahsedildiği gibi Avustralya yerlilerinin topyekün "medenileşemeyeceği" gerekçesi ile yok edilmesi ve yerine beyaz göçmenlerin yerleştirilmesi, İngiliz kolonyalizmi döneminde ve sonrasında Amerika Birleşik Devletleri’nin Kuzey Amerika yerlilerini sistematik biçimde yok etmesi ve Afrika kıtasının neredeyse bütünüyle köleleştirilmesi bu evrensellik ve homojenleştirme fikrinin bir tezahürdür. Amerika Birleşik Devletleri;'nin Bağımsızlık Savaşı'nın hemen ardından bir "Amerikalı" ulus inşa etme projesinin de çokkültürlülük vizyonundan uzak asimilasyoncu bir uyum modeli olması İngiltere kolonyalizminin bir ürünü olarak değerlendirilebilir.

Çokkültürlülük vizyonu bu noktada post-kolonyal dönemin ve günümüzün en yoğun tartışma alanlarından birisi olarak karşımıza çıkar. Kolonyal tecrübenin sonucu olarak farklı coğrafyalardan (örneğin Afrika'dan ABD’ye köle olarak göç etmeye zorlanan siyahiler) kolonilere göç eden farklı kültürlerden insanların nasıl bir arada yaşayacağı problemine çokkültürlülük vizyonu üzerinden cevaplar verilmektedir. En basit haliyle farklı etnik ve dini grupların bir arada yaşamasını ifade eden çokkültürlülük, ulusallığı ve aynı zamanda evrensellik iddiasını aşan bir tezdir. ${ }^{23}$ "Farklılıkların kutsanması" olarak değerlendirebileceğimiz çokkültürcülük birbirlerinden farklı oldukları için çatışma eğiliminde ya da çatışma halinde olan kültürel, etnik ya da dini birimlerin birbirleri üzerinde tahakküm kurup farklıkları ortadan kaldırma arzusuna tepki olarak ortaya çıkmıştır. Kolonyalizmin sömürgeleştirilen ulusları tahakküm altına alıp tek tipleştirmeye çalışması buna örnek verilebilir. Ancak Fay'in ifadesiyle çokkültürcülüğün "kültürel ve toplumsal bütünlüğe ve öteki birimlerin bütünlüğüne saygı duyulmasına vurgu yapıyor” olması başka bir sorunu da beraberinde getirmektedir: "Eğer biz kendi çevremizde ve ötekiler de kendi çevrelerinde yaşıyorlarsa, onları nasıl anlayabileceğiz?”24 Kolonyalizm realitesi kontekstinde değerlendirildiğinde çokkültürcülük de bir yerliyi ya da siyasi bir köleyi mutlak anlamda anlamamızı sağlayamayacaktır.

“Biz kendi çevremiz bağlamında düşünüyor ve davranıyoruz, ötekiler de kendi çevreleri bağlamında düşünüyor ve davranıyorlar; öyle ki, onları

teşkil edecek bir eser Alexis de Tocqueville tarafından kaleme alınmıştır. Bu metinde Fransa'nın Cezayir'i sömürgeleştirme motivasyonları ve Fransa'nın Cezayir'de yaptıklarının bir anlatısı sunulmuş ve eleștirisi yapılmıştır. Detaylı bilgi için bkz; Alexis de Tocqueville, Sömürge ve Kölelik: Öteki Üzerine Seçme Yazılar, der.: Lütfi Sunar, çev. Burak M. Nuri Gücin, Hasan Tunçkapı, Nuri Fudayl Kıcıroğlu, İstanbul, Ayrıntı Yayınları, 2016.

23 Ertan Özensel, “Çokkültürlülük Uygulaması Olarak Kanada Çokkültürlülüğü”, Akademik Incelemeler Dergisi, Sakarya 2012, Sayı: 1, s. 59.

24 Fay, a.g.e., s. 16. 
kendi bağlamlarından başka bir bağlamda mülahaza etmeye mecbur kalıyoruz. Onların bağlamı bizim bağlamımızdan özde farklılaştıkça biz onları o derece anlamaya mahkum oluyoruz. Etnik, cinsel, ırksal, dinsel, sinıfsal ve kültürel farklılıkları vurgulayan -ve insanların kendi tikelliklerini keşfetme ve koruma çabasında oldukları- çokkültürlü bir dünya, toplumsal bilginin parçalanmasına yol açıyor. Nihayetinde, bir türden insanların yalnızca aynı türden insanlar tarafından bilinebileceği noktasına varılıyor....AfroAmerikalıları yalnızca Afro-Amerikalılar bilebilir. Özetle söylemek gerekirse çokkültürcülük, olmakla bilmeyi eşitliyor." ${ }^{25}$

Kolonyalizm tecrübesinin yaralarını saracak bir yol olarak çokkültürcülük bütün açmazlarına ${ }^{26}$ rağmen günümüz kontekstinde en makul politika olarak görülebilir. Gerçekten de bugün kolonyalizm tecrübesinin ve evrensellik iddiasının sürüklediği yanlışlar ve ızdırapların yeniden yaşanmaması için çokkültürcülük vizyonu en geçerli vizyon olmayı sürdürüyor. Dolayısıyla bu noktada değerlendirilmesi gereken hususlar çokkültürcülüğün açmazlarının çözüme kavuşturulması ve daha iyi politikaların üretilmesidir. Günümüzde çokkültürcülüğü bir devlet politikası olarak uygulayan en önemli ülke olan Kanada bu noktada paradigmatik bir örnek teşkil etmektedir. ${ }^{27}$

\section{Kaynakça}

BALLYN, Sue, "The British Invasion of Australia. Convicts: Exile and Dislocation", Lives in Migration: Rupture and Continuity, ed. Martin Renes, Australian Studies Centre, University of Barcelona, Spain 2010.

EILLIOTT, John H., Empires of The Atlantic World: Britain and Spain in America1492-1830, Yale University Press, New Haven 2006.

FAY, Brian, Çağdaş Sosyal Bilimler Felsefesi: Çokkültürlü Bir Yaklaşım, çev. İsmail, Türkmen, Ayrıntı Yayınları, İstanbul, 2017.

FERGUSON, Niall, Imparatorluk: Britanya'nın Modern Dünya'yı Biçimlendirişi’”, çev. Nurettin Elhüseyni, Yapı Kredi Yayınları, İstanbul, 2013.

FORSTER, Edward Morgan, A Passage To India, Cambridge: Penguin Classics 2005.

LANGE, Matthew, Lineages of Despotism and Development: British Colonialism and State Power, University of Chicago Press 2014.

LAS CASAS, Bartolomeo de, Yerliler'in Gözyaşları: Yerlilerin Yok Edilişinin Kısa Tarihi, çev. Oktay Etiman, İmge Kitabevi, Ankara, 2014.

25 Fay, a.g.e., s. 17.

26 Çokkültürcülüğün açmazlarına yönelik detaylar için bkz. Brian Fay, Çağdaş Sosyal Bilimler Felsefesi: Çokkültürlü Bir Yaklaşım, çev. İsmail, Türkmen, İstanbul, Ayrıntı Yayınları, 2017.

27 Paradigmatik bir çokkültürcülük örneği olarak Kanada çokkültürcülüğü için bkz. Ertan Özensel, “Çokkültürlülük Uygulaması Olarak Kanada Çokkültürlülüğüu, Akademik İncelemeler Dergisi, Sakarya 2012, Sayı: 1, ss. 55-70. 
MEMMI, Albert, Sömürgecinin ve Sömürgeleştirilenin Portresi, çev. Şen Süer, Versus Kitap, İstanbul, 2014.

ÖZCAN, Azmi, "İngiliz Sömürgeciliğinin Doğuşu ve Aşamaları", Sömürgecilik Tarihi (AfrikaAsya), ed. Azmi, Özcan, T.C. Anadolu Üniversitesi Yayını No:3120, Eskişehir, 2014.

ÖZENSEL, Ertan, “Çokkültürlülük Uygulaması Olarak Kanada Çokkültürlülüğü”, Akademik Incelemeler Dergisi, Sakarya 2012, Sayı: 1, ss. 55-70.

PAREKH, Bhikhu, "Indian Conceptualization of Colonial Rule", Colonialism and Its Legacies, ed. Jacob, T. Levy, Lexington Books, Maryland 2011.

ŞAN, Mustafa; Haşlak, İrfan, "Asimilasyon ile Çokkültürlülük Arasında Amerikan Anaakımını Yeniden Düşünmek”, Akademik incelemeler Dergisi, Sakarya 2012, Sayı: 1, ss. 29-54.

TOCQUEVILLE, Alexis de, Sömürge ve Kölelik: Öteki Üzerine Seçme Yazılar, der. Lütfi Sunar, Çev. Burak M. Nuri Gücin, Hasan Tunçkapı, Nuri Fudayl Kıcıroğlu, Ayrıntı Yayınları, İstanbul, 2016.

YAYLI, Hasan, "Mekanik Düşünceden Ekolojik Düşünceye: Yeni Bir İnsan-Doğa İlişkisi Tasarımının Doğuşu", Sosyoloji Konferansları Otuzdördüncü Kitap, İstanbul Üniversitesi Yayınları, İstanbul, 2006. 